\title{
UMA DISCUSSÃO SOBRE O CONCEITO DE METRÓPOLE
}

\section{A Discussion on the Concept of Metropolis}

Pof $^{\text {a }}$. Dra . Tânia Maria Fresca

Universidade Estadual de Londrina Programa de Pós-Graduação em Geografia da Universidade Estadual de Maringá Av. Colombo, 5790, Jardim Universitário, CEP.: 87020-900, Maringá (PR), Brasil

Tel.: (44) 3261-4731 - tania_geografia@yahoo.com.br

\section{aaAaa}

\begin{abstract}
Resumo
Metrópole é um termo marcado por diferentes conceitos e abordagens, que vem sendo discutido por diferentes autores e teorias desde o final do século XIX. Marcado pela polissemia, apresenta diferentes interpretações no último século, denotando tratar-se de um objeto que é fluido no tempo e espaço. Neste sentido, busca-se uma contribuição ao entendimento do mesmo não como recurso a uma definição ou conceito per si de metrópole, mas, abordagens oriundas de uma seleção, porque não há uma resposta ou análise única, mas uma interpretação plausível, ainda que submetida a transformações.
\end{abstract}

Palavras-chave: Metrópole, Natureza conceitual, Funcionalidade, Espaço urbano.

\begin{abstract}
Metropolis is a term marked by different concepts and approaches, which has been discussed by different authors and theories from the late nineteenth century. Marked by polysemy, has different interpretations in the last century denoting that's an object that is fluid in time and space. Accordingly, seeks a contribution to the understanding of it not to an definition or use of the concept per se of the metropolis, but approaches arising from a selection, because there is no answer or a single analysis, but a plausible interpretation, even if subject to transformations.
\end{abstract}

Key words: Metropolis, Conceptual nature, Functionality, Urban space.

\begin{abstract}
Resumen
Metrópolis es una palabra marcada por diferentes conceptos y enfoques, que ha sido debatida por diferentes autores y teorías desde finales del siglo XIX. Marcada por la polisemia, presenta diferentes interpretaciones en el siglo pasado, lo que denota que es un objeto fluido en el tiempo y el espacio. En este sentido, la búsqueda es una contribución a la comprensión de la misma no es como un recurso a una definición o concepto de metrópolis, pero los planteamientos de una selección, porque no hay respuesta o análisis solamente, sino una interpretación plausible, incluso si están sujeta a transformaciones.
\end{abstract}

Palabras clave: Metrópolis, Carácter conceptual, Funcionalidad, Espacio urbano.

\section{aaCaa}




\section{INTRODUÇÃO}

O trabalho efetua um resgate de diferentes conceitos e abordagens da metrópole, como uma contribuição ao entendimento da natureza da metrópole a partir de diferentes autores, teorias e temporalidades. Isto porque o conceito de metrópole é polissêmico, apresentando diferentes interpretações ao longo dos últimos 120 anos, denotando-se tratar de um objeto que é fluido no tempo e espaço. No entanto, verifica-se que nesta evolução conceitual não houve mudanças abruptas, pois no avanço do modo de produção capitalista criou-se raízes ao longo do tempo, permitindo que conceitos se consolidassem sem rupturas essenciais. Situação exemplar é que o telégrafo, telefone, imprensa rotativa, rádio, aviação, televisão e telemática são técnicas da continuidade do domínio do espaço pelo tempo. Assim, este trabalho não procura definição ou conceito per si de metrópole, mas abordagens oriundas de uma seleção porque não há uma resposta ou análise única, mas uma interpretação plausível, ainda que submetida a transformações. Nas distintas interpretações identifica-se que elas congregam ideias semelhantes e diferentes entre si e de modo geral, há dois enfoques predominantes: 1) os que analisam funcionalidade metropolitana, isto é, as atividades econômicas em suas diversas escalas de atuação, e 2) os que analisam os mais distintos aspectos da complexa produção do espaço urbano metropolitano.

\section{AS ATIVIDADES ECONÔMICAS METROPOLITANAS}

Os estudos sobre a natureza da metrópole tendo como foco a discussão funcional, têm diversas abordagens, a começar por aquelas vinculadas à Escola de Chicago. Nesta, a metrópole é abordada a partir do conceito de comunidade e a despeito desta interpretação, não discutir-se-á por não ser pertinente aos objetivos do presente trabalho. Além do mais, críticas diversas já foram efetuadas, importando-nos no momento, a compreensão da dimensão funcional da metrópole desenvolvido naquele contexto.

Gras (1974), Bogue (1974), Dickinson (1974), Park (1974) são alguns dos autores vinculados à Escola de Chicago que analisaram a metrópole nesta dimensão. Em tal abordagem, entendem a economia metropolitana como sendo a concentração de todo o comércio de uma ampla área de uma grande cidade; e a metrópole como o ponto central para a zona de influência, bem como para o comércio entre unidades metropolitanas. Para Gras (1974), o aspecto fundamental da metrópole não é a sua dimensão ou estrutura, mas sua força funcional na medida em que concentra o comércio de ampla zona, sendo ponto de convergência de produtos comerciais e agrícolas. Dela partem inúmeros produtos de diferentes setores, gerando comerciantes especializados. Dickinson (1974) acrescenta que esta cidade terá população consideravelmente superior àquelas cidades circundantes; será um centro comercial independente, com grande variedade de atividades regionais e forte atividade atacadista, além de centro financeiro, cultural e administrativo. Deriva de tal entendimento, o fato de Bogue (1974) considerar os centros metropolitanos como os maiores e mais complexos, pois está em posição de produzir e distribuir bens e serviços.

Mas,a ideia fundamental para o entendimento da natureza da metrópole verifica-se com Gras (1974) ao discutir os fatores marcantes do desenvolvimento metropolitano. Tendo por base a cidade de Londres, estabelece quatro etapas deste desenvolvimento. A primeira vai de 1550 até 1750, e é entendida como a etapa da organização do comércio atacadista local, regional e internacional; momento da profusão das grandes companhias comerciais para importação e exportação, sendo estas, de caráter metropolitano, já que seus proprietários, diretores e escritórios, localizavam-se na metrópole.

A segunda etapa vai de 1750 a 1830, na qual ocorreram profundas transformações na produção industrial, marcada pelo deslocamento das fábricas do campo para as cidades ou locais com fontes de energia hidráulica, minas de carvão e facilidade de transporte. Mas, Londres não tornou-se lócus da produção industrial nesta fase em razão de não apresentar as condições necessárias a esta produção, permanecendo apenas a fabricação de artigos de luxo. 
A terceira etapa vai de 1830 a 1890, correspondendo em linhas gerais, à revolução dos transportes e comunicações mediante a introdução dos correios com sede na metrópole; mas, o destaque foi o transporte ferroviário cujas linhas se dirigiam para a metrópole e desta forma, toda a área de influência a ela estava dirigida garantindo maior e melhor controle via comércio regional, sistema bancário, comunicações, dentre outros. Adiciona-se o transporte marítimo ampliado com o navio à vapor, aumentando, exponencialmente, o comércio internacional, cujas empresas e proprietários estavam sediados na metrópole, a partir da qual exercia-se o controle das atividades, ampliando o poder metropolitano.

A quarta fase do desenvolvimento metropolitano para Gras (1974), principiada em 1890, foi marcada por uma nova concentração do poder financeiro no seio da metrópole. "[...] dicha concentración podía observarse durante las fases anteriores, pero después de la revolución en los transportes se convertió en la tendencia dominante" (GRAS, 1974, p. 330). Isto porque os bancos privados cujas sedes estavam na metrópole, criaram filiais subordinadas diretamente às sedes; criou-se as condições para que a metrópole fosse o local de concentração do capital, decisões, enfim, de outra forma de poder econômico.

Observa-se que as etapas indicadas pelo autor estão fortemente apoiadas no desenvolvimento do sistema capitalista a partir de sua fase comercial. A Inglaterra, como país da primeira revolução industrial, criou condições históricas para que Londres, a capital política do país, fosse, gradativamente, incorporando atividades urbanas a reforçarem seu poder econômico. Neste sentido, a metrópole londrina é fruto da primeira revolução industrial e dela pode tirar proveito após, principalmente, os avanços do transporte marítimo. Foi a partir de então que o comércio internacional passou a ser uma das atividades fundamentais para o poder da metrópole, já que se tornou a única - durante certo tempo - a comercializar em escala mundial a sua produção industrial.

Desta forma, acabou por realizar um processo de acumulação horizontal no sentido de que sua expansão foi marcada pela conquista de mercados consumidores cada vez mais amplos, graças a fortes investimentos em inovações para a produção. Desta dinâmica econômica deriva a implantação e expansão de atividades urbanas ligadas ao controle econômico, como as companhias comerciais, seguradoras, bancos, escritórios diversos, dentre outros serviços. Vale salientar que na análise precedente não há destaque para o papel da metrópole como local da produção industrial, derivando isto da própria história da revolução industrial inglesa, cujas unidades produtivas fabris foram instaladas junto às fontes de matérias-primas e energia hidráulica, criando cidades e a região metropolitana (CHARDONETT, 1959)

Com relação aos EUA, Gras (1974) demonstra haver diferenças para com a Inglaterra, a começar pelo fato que nos EUA o sistema financeiro foi estruturado de modo mais disperso, concentrando-se em várias cidades. Argumenta Gras (1974) que o desenvolvimento metropolitano nos EUA se realizou a partir do comércio atacadista, enquanto os subúrbios industriais concentraram a maior parte do que foi abandonado pelo setor metropolitano industrial após o período da descentralização. Embora o autor não faça referência temporal ao processo de descentralização industrial, Haig (1968) escreveu que na década de 1920 este processo estava em vigor nos EUA. Assim, os terminais ferroviários e portuários indicam a zona de encontro do comércio generalizado. Por fim, o distrito financeiro com a casa da moeda, bolsa de valores, bancos, escritórios de seguros constituíam o ponto sensível do centro metropolitano. Vale notar que, em 1922, o autor já identificava no nordeste dos EUA forte concorrência entre metrópoles, cujo desenvolvimento seguia quatro direções principais: três no sentido leste-oeste e uma norte-sul. Dentre todas, Nova York era a mais importante e iria configurar a futura megalópole. Desta forma, “[...] La metrópoli desempeña una serie de funciones y la transtierra otras. Ambas son a la vez industriales, comerciales y financeiras, pero la metrópoli es predominantemente comercial y financeira" (GRAS, 1974, p. 332).

Os EUA sendo um dos líderes da segunda revolução industrial no final do século XIX, pode rapidamente incorporar os avanços técnicos - aço, energia elétrica, motor à explosão, telégrafo, 
etc. - à produção industrial, criando outras condições para o desenvolvimento da metrópole. Uma delas foi a rapidez com a qual a produção industrial foi desconcentrada para cidades do entorno da metrópole, favorecida pelo transporte ferroviário e energia elétrica (NIVEAU, 1969). Vale notar que desde o final do século XIX estava em marcha o processo de centralização do capital com a constituição dos trustes, cartéis e fusões de empresas, constituindo-se a etapa monopolista do sistema capitalista. Os EUA rapidamente expandiram suas atividades, e controlaram parcela cada vez maior das produções e tornou-se no final da década de 1910, centro financeiro dominante (NIVEAU, 1969, p. 219). Nestas circunstâncias, encontram-se alguns dos elementos para o entendimento do fato de suas metrópoles apresentarem funções predominantemente comerciais, financeiras e outros serviços ligados à gestão e poder econômico.

Advém das interpretações apoiadas em Gras (1974) e Bogue (1974), uma série de estudos para a identificação de cidades que poderiam ser consideradas metropolitanas, a delimitação das regiões metropolitanas, a interpretação das funções das cidades metropolitanas em relação ao caráter econômico de suas regiões de influência, dentre outros. Destaque nestes aspectos, é o trabalho de Dickinson (1974) que a partir do índice per capita de vendas de produtos industriais comercializados no atacado e varejo, identificou 38 cidades com caráter metropolitano. No entanto, estabeleceu diferenciação entre as áreas metropolitanas dos EUA ligadas às distintas dinâmicas econômicas regionais.

Outra abordagem sobre a funcionalidade da metrópole é a de Berry e Horton (1970). Ao discutirem os problemas da definição da metrópole no contexto dos EUA, efetuaram críticas aos procedimentos adotados pelo Standard Metropolitan Area - SMA, afirmando que o critério populacional e as migrações pendulares para o trabalho não são suficientes para entender e classificar as metrópoles. Os autores propõem outro sistema de classificação apoiado: a) no domínio metropolitano expresso pelo sistema de transporte, telefonia e domínio comercial; b) na identificação da especialização funcional da metrópole mediante a venda por atacado, comércio varejista, bancos, serviços, receitas municipais, valor adicionado da indústria; c) na identificação da área funcional econômica através das áreas de mercado de trabalho, isto é, seja comercial, industrial, serviços; d) na área econômica estatal através de agências e órgãos públicos de controle e investimentos bem como do planejamento; e) nas comunidades urbanas de área de interesse, referente ao fato que as grandes áreas metropolitanas não constituem uma única área de mercado, seja para trabalho e consumo (BERRY; HORTON, 1970). Mas, como forma de apoiar suas críticas aos critérios do SMA, dão destaque aos deslocamentos para o trabalho no âmbito metropolitano, identificando algumas características gerais das mesmas, bem como efetuaram outras propostas. Desta forma, denomina de campo de deslocamentos: a área que abrange todos os deslocamentos diários para uma área de trabalho; de mercado de trabalho todos os municípios de envio diário de migrantes pendulares para trabalhar em uma cidade principal; de área econômica funcional todos aqueles municípios dentro de um mercado de trabalho em que a proporção de trabalhadores residentes que se deslocam a um município central é superior à proporção daqueles que se deslocam a municípios alternativos; e de regiões urbanas consolidadas a comutação de pelo menos 5\% dos trabalhadores residentes de um município central para outro município central (BERRY; HORTON, 1970, p. 270-271).

Denota-se da interpretação dada pelos autores, que a identificação e classificação das metrópoles envolve um conjunto bastante amplo de critérios, cujo foco principal é a funcionalidade. Neste conjunto, o sistema de transporte, comunicação, comércio e migrações pendulares estabelece a área de influência da mesma, enquanto os dados sobre produção, circulação e mercado de trabalho permite entender a especialização funcional, ligada ao papel que a mesma desempenha na divisão territorial do trabalho. Do ponto de vista econômico, a presença de agências e órgãos estatais e sua área de atuação é mais um elemento para analisar e classificar uma cidade como metrópole. Note-se bem que os critérios levam em conta o poder econômico em suas diferentes manifestações como base para o entendimento de uma cidade como metrópole. 
Outra abordagem sobre o caráter funcional da metrópole tem-se com Gottmann $(1959,1966$, 1976, 1990), quando o autor chama a atenção para o fato de que, desde início do século XX, ocorria a tendência da produção industrial deixar as grandes cidades, desconcentrando-se mediante pressão dos custos, congestionamentos, taxas, regulamentações diversos em direção ao movimento para fora das grandes cidades. Para o autor, a produção industrial é tida como um dos elementos importantes para a funcionalidade da metrópole, mas a desconcentração física desta produção não implicou em perda de seu poder. Isto porque, segundo Gottmann $(1976$, p. 6), as grandes cidades "[...] mantiveram o controle geral da economia industrial e a função de incubadora". A partir das relações entre desconcentração industrial, migrações e avanços tecnológicos, o autor afirma que o emprego industrial diminuia enquanto nos serviços era ampliado, principalmente nos setores administrativos, técnicos e escritórios. A separação geográfica entre produção e controle, gestão e laboratórios ampliou o número destes empregos, que ele denominou de ocupações quaternárias e que permitiram o contínuo crescimento das grandes cidades. As atividades quaternárias, para o autor, consistem "[...] basicamente de transações abstratas. A categoria mais importante de materiais por ela manipulada é a informação. Os planejadores japoneses já falam de uma 'sociedade de informação' (GOTTMANN, 1976, p. 9), na qual os elementos mais importantes são os software e hardware.

Na medida em que houve melhorias no sistema de transporte e comércio mundial, as funções econômicas no espaço puderam se desenvolver na escala nacional e internacional, privilegiando as cidades que constituem os centros das grandes redes econômicas, mas atingiram, mediante divisão "[...] auto-aperfeiçoadora do trabalho" centenas de cidades de "[...] tamanho médio com atividades especializadas e centralização regional que exigem participação nas redes mais amplas" (GOTTMANN, 1976, p. 9). Neste percurso, segundo o autor, ocorreu nova etapa de desenvolvimento das metrópoles, pois o funcionamento das atividades políticas e das grandes empresas privadas passou a ser realizado, em grande parte, mediante processamento de informações. Para tanto, exige-se infra-estrutura do tipo tecnológico complexo, além de trabalhadores qualificados e equipamentos como laboratórios, institutos de pesquisas, universidades, bibliotecas bem como outros serviços públicos intimamente relacionados ao setor privado, hospedagem, transporte aéreo, turismo, etc. Gottmann (1976, p. 10) ressalta que essa nova forma de centralização da metrópole gera "[...] interdependência entre as várias categorias de atividades aglomeradas nas grandes cidades que usam pessoal quaternário". Mais que isso, pois o autor chama a atenção para o fato de que as ligações e complementações entre as várias metrópoles, tornou-se necessidade imperativa para atuarem intensivamente em uma rede urbana mundial. Estas ligações têm, nas corporações multinacionais, uma das redes internacionais de grande significado para a metrópole.

Novos elementos foram introduzidos para a compreensão da metrópole a partir de Gottmann (1976), agora local do poder assentado em redes de comunicações e informações, tendo nas sedes das grandes empresas o elemento de integração. Isso não significa que anteriormente as grandes corporações multinacionais não se fizessem presentes nas metrópoles, mas o diferencial são os mecanismos de controle da produção industrial que passou a ser muito mais dispersa, apoiados na informação.

Destaque deve ser dado a Hall (1966), um dos primeiros a discutir as "cidades mundiais" termo emprestado de Patrick Geddes - entendidas a partir de seus múltiplos papéis como centros de poder político a nível nacional e internacional, da concentração de órgãos e empresas governamentais, centros de comércio nacional e internacional atuando como entrepostos para seus países ou para países vizinhos, centros de serviços bancários, seguros e outros serviços financeiros, centro de atividade profissional avançado de todos os tipos - medicina, jurídico, ensino superior, aplicação do conhecimento científico à tecnologia - centros de concentração de informação e difusão através de publicações e da mídia de massa, centros de consumo de luxo e de bens produzidos em massa para a grande maioria da população, centro das artes, cultura e entretenimento e de atividades auxiliares diversas (HALL, 1966, p. 7-8). 
Para o entendimento das metrópoles em meados do século XX, o autor o faz associando com fases do desenvolvimento industrial, principalmente após meados do século XIX, quando o ritmo de invenções e inovações tecnológicas se fez mais rapidamente, com implicações no desenvolvimento das metrópoles. Desta forma, as invenções dos circuitos elétricos, telefonia, motor à explosão, descoberta do petróleo, etc., que Hall (1966) denominou de neotecnologias, permitiram que as indústrias ao adotarem as mesmas, o fizessem baseadas no princípio da descentralização, ou seja, mais distantes das fontes de matérias-primas e mais próximas das metrópoles. Tais tecnologias auxiliaram a partir de 1870, uma série de transformações nas empresas industriais, que foram gradativamente passando de empresas familiares para sociedades acionárias e cuja direção das mesmas passaram a ser realizadas por dirigentes financeiros. Estava em curso o processo de expansão do capitalismo financeiro, em que o dirigente se situa no domínio das finanças, nas decisões sobre a produção e comercialização, localizado na metrópole. Em outras palavras, passava-se da fábrica para o escritório o controle da unidade produtiva.

Outras invenções contribuíram para a criação do moderno escritório de controle da produção industrial como o estenógrafo, elevador, máquina de calcular, papel carbono, etc., permitindo outra valorização do pessoal administrativo. Tanto assim que Hall (1966) afirma que a evolução destas técnicas provocou maior desenvolvimento da vida urbana; porque, se a indústria neotécnica se adaptou a descentralização, na administração ocorreu o mesmo. No sistema capitalista sob o signo das finanças, dos escritórios, dos serviços públicos, sociedades de investimentos no exterior, se desenvolveu nas proximidades de tais instituições, serviços de contabilidade, agências de publicidade, conselhos de organização comerciais. Desse modo, no início do século XX, o papel do crescimento dos poderes públicos na vida econômica e social se traduzia por um aumento muito forte do número de postos administrativos em todas as capitais políticas (HALL, 1966). Entende o autor, que a multiplicação dos empregos de escritórios de toda sorte foi provavelmente uma das principais causas do crescimento das cidades em meados do século XX, juntamente com a expansão do comércio varejista. Em outras palavras, o autor já reconhecia a importância dos serviços para o desenvolvimento metropolitano, principalmente aqueles ligados à adminstração das indústrias sob a égide do capital financeiro.

A partir destes enfoques, pode-se encontrar diversos estudos sobre esta nova etapa da funcionalidade metropolitana como os estudos de Pred (1979), Malecki $(1979,1980)$, Semple $(1985,1996)$, dentre outros. Em comum entre os citados está a busca pelo entendimento dos centros de atividades quaternárias, o controle das atividades e sistemas de cidades, bem como a distribuição dos centros de pesquisas das grandes corporações, tendo a metrópole como a mais importante neste conjunto.

Para Pred (1979, p. 97) as grandes empresas multilocalizadas (privadas e públicas) dominam a economia sendo direta ou indiretamente as maiores geradoras de empregos, implementadoras de decisões locacionais e as maiores geradoras de fluxos de bens, serviços, capital e informações especializadas. O crescimento do poder das grandes corporações deriva de fusões, aquisições, expansão física das unidades produtivas e investimentos de capitais, principalmente após a segunda Guerra Mundial. Para o autor, a relação entre corporação e localização sugere a evidência de vínculos intraorganizacionais ao padrão de transmissão interurbana de crescimento das cidades. Isto porque a complexidade da interdependência varia conforme a divisão do trabalho intraorganização e a divisão do trabalho mais ampla entre empresas e firmas.

Mediante avanços das telecomunicações, transporte aéreo, novas tecnologias industriais, ampliou-se o número de unidades especializadas que ofertam partes, peças, componentes e que apresentam diferentes localizações. Assim, as empresas multilocacionais desenvolveram vínculos complexos de interdependência entre suas unidades (quer estejam próximas ou dispersas). Vínculos esses para fluxos de serviços, controle e coordenação, gerando aumento de empregos quaternários. Desta forma, a estrutura espacial das corporações multilocalizadas, são hierárquicas e assimétricas com três ou mais escalões - nacional, regional, local - e cada unidade de um escalão mais elevado, 
atende uma área cada vez mais ampla. No topo da hierarquia está a sede, localizada, sobretudo na metrópole, por causa das economias externas, com facilidade de contatos interorganizacionais, disponibilidade de serviços comerciais, consultorias diversas, informação e acessibilidade (PRED, 1979, p. 115). Neste sentido, as corporações influenciam no crescimento das cidades pelos efeitos multiplicadores, pela difusão de inovações criadoras de empregos e pela acumulação de decisões fundamentais para a sobrevivência das corporações.

Semple (1985) por sua vez, correlaciona os centros de atividades quaternárias com a localização das atividades de controle, da tomada de decisões e a natureza da estrutura organizacional. As grandes organizações econômicas muito poderosas, são capazes de criarem novos quadros regionais, alterando a organização espacial. Como são organizadas espacialmente em termos hierárquicos, definem uma correspondente estrutura de atividades quaternárias no sistema de cidades. Por centros de atividades quaternárias, entende "[...] o conjunto de atividades de comando, controle, decisão e coordenação" (SEMPLE, 1996, p. 352). Ao mesmo tempo explica que "[...] o princípio central da análise quaternária é que a sede das funções gerenciais são separadas das unidades operacionais, uma vez que as corporações estabelecem a elite de suas equipes de gestão nos escritórios centrais ou suburbanos, afim de maximizar sua eficácia (SEMPLE, 1996, p. 353).

Segundo Semple (1985), a evolução dos lugares quaternários está articulada, historicamente, ao processo de descentralização das empresas, que foi realizada em 5 etapas nos EUA, indo da dispersão para a concentração. Num primeiro momento, a produção e decisão estavam dispersas e especialmente indiferenciadas; num segundo momento atinge centros maiores, alcançando no terceiro o centro nacional de controle, concentrando as principais corporações; seguidamente atinge - se vários outros centros com modernos sistemas de comunicação e, por fim, alcança-se a emergência de centros de controle internacional. Neste sentido, o autor estabelece a possibilidade de identificar a importância dos lugares quaternários baseada na estrutura dos modernos centros empresariais.

Com relação ao papel das metrópoles como centros de pesquisa das grandes corporações, Malecki (1979) demonstra que as atividades de pesquisa e desenvolvimento - P\&D - tendem a se aglomerar em grandes áreas urbanas onde são comuns as pesquisas universitárias, produção e sede de corporações. Acrescente-se ainda o fato de que as metrópoles apresentam vantagens aos seus quadros especializados em termos de cultura, recreação, etc. Mas, adverte que a importância da localização dos centros de pesquisa e desenvolvimento, varia de indústria para indústria, podendo inclusive se fazer presente em centros urbanos de menor porte onde há universidades ou centros de pesquisas articulados a uma atividade industrial.

De modo mais generalizado, Beaujeau-Garnier (1980) também entende as cidades como espaços financeiros privilegiados, com destaque para as metrópoles, em que se concentram as sedes sociais dos bancos e de modo hierárquico estabelecem controle sobre vastos territórios e países. Para a autora, o poder de comando da cidade - e aqui se acrescenta as metrópoles - se realiza pelo fato: de ser a sede do poder oficial, exercido através da administração burocrática; pela densidade e importância dos equipamentos coletivos; pelos recursos da população mediante impostos e taxas; ser sede do poder de informações no sentido lato; ter domínio da organização funcional de vastos espaços urbanos e rurais; ser sede do poder econômico mediante consumo, salários, disponibilidade de capital para investimentos, sejam eles endógenos ou exógenos à metrópole; pelos fluxos de trocas; dentre outros. Neste sentido, a divisão social do trabalho representa o nível das funções, particularmente as sedes sociais das empresas, que para a autora é o apanágio das grandes cidades e metrópoles. Desta forma, o destaque é a transmissão da ação do poder central em relação ao qual a metrópole tem papel privilegiado.

Se até o momento as análises envolveram fundamentalmente o entendimento da natureza conceitual da metrópole a partir de suas atividades econômicas, destacando-se numa primeira fase o comércio, a produção industrial e o sistema bancário, a partir da Segunda Guerra Mundial as análises destacaram o papel dos serviços especializados ou quaternários Gottmann (1990), bem como 
o papel das corporações e a contínua importância do desenvolvimento tecnológico para o poder metropolitano, porque é disto que se trata em essência, o desenvolvimento de inúmeras atividades econômicas na metrópole.

Mas, a partir dos anos de 1990, a temática sobre as metrópoles volta a ter grande destaque, emergindo outras terminologias e diferentes enfoques. É o caso da cidade informacional (CASTELLS, 1999), cidade global (SASSEN, 1998), pós metrópole (SOJA, 2002), cidade-região global (SCOTT et AL., 2001), arquipélago urbano (VELTZ, 1996), metápole (ASCHER, 1995, 2011), dentre outros.

Davidovich (2004, p. 201) entende que o retorno das metrópoles ao debate em escala mundial estava articulado diretamente aos novos direcionamentos das políticas do Banco Mundial, que passou a focalizar as mesmas, como motor do crescimento econômico. Ora, o Banco Mundial em suas diversas formas de poder, investimentos e capacidade de direcionar movimentos de expansão do capital, particularmente dos EUA e países europeus, acabou por privilegiar as metrópoles em uma etapa em que a globalização estava em expansão. Mais que isso, tratava-se ainda da busca de novos campos de investimentos para fazer frente a sucessivos momentos de crises econômicas e as concepções em uso da globalização, permitiam outra etapa de expansão das grandes corporações em atividades diversas em escala mundial. Não é por acaso que maioria das privatizações das estatais brasileiras em serviços públicos como telefonia, energia, transporte e na produção propriamente dita, ocorreu a partir dos anos de 1990.

Dos autores mencionados acima, há em comum o entendimento de que as metrópoles tornaram-se os principais nós de redes da economia mundial, facilitado pelo comando das modernas tecnologias de informação e que as mesmas desempenham cada vez mais funções ligadas aos serviços superiores em detrimento de serem lócus da produção industrial. Em comum ainda está o fato de terem na globalização, parcela considerável de suas análises em direção ao entendimento dos atuais elementos do poder metropolitano via corporações multinacionais e sistema financeiro.

Deriva destes elementos comuns, a posição de Friedmann (1986) e Friedmann e Wolf (1982) que diante do papel desempenhado pelas grandes corporações no que tange à produção e o tratamento das informações, ocorreu certa hierarquia mundial entre as metrópoles: aquelas que efetuam as articulações financeiras globais como Nova York, Londres, Tókio; aquelas que efetuam articulações multinacionais como Miami, Los Angeles, Frankfurt; as mais importantes nacionais como Paris, Madri, São Paulo, todas formando uma rede mundial. E como as redes assumem papel crucial nas análises das metrópoles, tem-se a posição de Castells (1999), para quem a economia vive a revolução das tecnologias de informação, processamento e comunicação. Portanto, uma economia informacional, entendida a partir da produtividade e competitividade ligada ao uso eficiente da informação baseada no conhecimento global "[...] porque as principais atividades produtivas, o consumo e a circulação [...] estão organizadas em escala global" (CASTELLS, 1999, p. 87). Advém desta compreensão, a noção de cidade informacional referida ao fato de concentrar os elementos chaves das redes de telecomunicações, permitindo descentralização da produção e atividades, comandadas a partir de fluxos diversos.

Diante da economia global e sociedade informacional, segundo o autor, tem-se uma nova forma espacial que são as megacidades, que além de elevado contingente populacional, são os nós da economia global, concentrando as " "...] funções superiores direcionais, produtivas e administrativas de todo o planeta; o controle da mídia; a verdadeira política do poder; e a capacidade simbólica de criar e difundir mensagens" (CASTELLS, 1999, p. 428). Em outras palavras, as megacidades são, em realidade, metrópoles que estão se tornando uma unidade econômica, funcional e socialmente interdependente. Ressalta-se ainda que entre as cidades há uma hierarquia na geração de riquezas, processamento de informação e poder, oriundos dos principais processos dominantes do capitalismo que articulados em rede, atribuem a cada lugar um papel e um peso distinto (CASTELLS, 1999, p. 439).

Ascher (2011) entende já não ser mais suficiente o conceito de metrópole para dar conta das transformações que afetaram as grandes cidades. Entende o autor "[...] que a metropolização apa- 
rece como uma 'etapa' ou 'fase' do processo de urbanização supra-histórico e a metápole como uma forma urbano co-estruturada pelo uso de novas tecnologias de comunicações e deslocamento de bens, pessoas e informação" (ASCHER, 2011, n. p. ). Em outros termos, a metápole refere-se a um conjunto de espaços onde a totalidade ou a maior parte dos habitantes e atividades econômicas estão integradas na funcionalidade cotidiana da mesma, constituindo-se em uma grande bacia de emprego, habitação e atividades que não se realizam contiguamente, haja vista que a metápole pode conter várias metrópoles.

A posição de Sassen (1998) também não difere muito em relação ao fundamento funcional das metrópoles, por ela denominada de cidades globais. Sua tese baseia-se no fato de que as transformações ocorridas nas últimas décadas do século XX - desenvolvimento das telecomunicações, ampliação da indústria de informação, dispersão das atividades econômicas, dentre outras - criaram novas formas de centralização territorial, relativas ao gerenciamento e controle das operações de mais alto nível nas grandes cidades, as globais. São cidades globais porque tornaram-se "[...] pontos de comando da organização da economia mundial; lugares das finanças e serviços especializados para grandes empresas; lugares de produção de inovações para as indústrias" (SASSEN, 1998, p. 16-17).

Veltz (1996) entende que no final do século XX, a metropolização da economia se afirma conformando as chamadas economias de arquipélagos, cujas principais aglomerações desempenham papéis fundamentais em redes nacionais e internacionais e as metrópoles se inserem segundo diferentes padrões. Estes variam em função da infraestrutura de comunicação e transporte tornando-se nós destas infraestrutura e da presença de multinacionais na metrópole. Trata-se, portanto, da concepção de uma rede-arquipélagos formada por grandes metrópoles que concentram parte crescente da riqueza, saber e poder.

Soja (2002) por sua vez, trata da pós-metrópole cujo prefixo é para acentuar a fragmentação das novas formas e conteúdos da metrópole e as implicações na sociedade sob crises e reformulações do sistema capitalista. Assim a pós-metrópole pode ser melhor entendida a partir de seis discursos que contribuem para a representação de sua complexidade: flexcity, cosmopolis, exopolis, metropolarities, carceral archipelagos e simcities.

O primeiro diz respeito à reestruturação econômica da pós-metrópole, provocando reconfiguração dos padrões e especificidades da forma urbana e das funções. A cidade flexível marca a decadência dos setores industriais e o crescimento de um largo setor de economia informal, a partir do qual se pode verificar desconcentração e reconcentração, heterogeneidade e homogeneidade, nucleação e espraiamento, dentre outros. A cosmópolis por sua vez, aborda o papel da pós-metrópole na estruturação de novas hierarquias econômicas vinculadas à globalização, enquanto o discurso da exópolis vincula-se à reengenharia do formato urbano ou as questões urbanísticas ligadas ao crescimento de cidades-satélites e a redefinição dos limites da pós-metrópole. A metrópole polarizadora socialmente permite o entendimento da reestruturação que ocorre mediante o rompimento da dicotomia centro-periferia, pois as periferias estão no centro e isso cria fluxos contínuos entre as diversas áreas. A cidade carcerária aborda a questão da produção de formas urbanas como os condomínios fechados, vigilância eletrônica, etc., criados e manipulados em direção a uma regulação social e espacial. Por fim, o discurso do simcity marca a reconstituição do imaginário urbano marcado pelos simulacros.

Nesta perspectiva, o autor leva em consideração tanto os aspectos da dinâmica funcional da metrópole como da organização intraurbana da mesma, mas o destaque é para a morfologia urbana, depreendendo-se de sua análise que a metrópole continua a ser caracterizada pela continuidade do processo de desconcentração da produção industrial e ampliação das atividades de serviços, num contínuo processo de desconcentração e reconcentração.

Scott et. al. (2001, p. 11) por sua vez, tratam das cidades regiões-globais entendidas como "[...] nós espaciais essenciais da economia global e como atores políticos específicos na cena mundial”. Tendo por pressuposto a globalização, a partir da qual ocorreu o processo de reestruturação pro- 
dutiva, marcado por flexibilização na acumulação do capital, nas relações de trabalho, na perda de parcela do poder dos Estados, na expansão de blocos multinacionais como União Européia, Mercosul, etc., os autores analisam as cidades-regiões como motores da economia global. Entendem que o aperfeiçoamento de tecnologias de desenvolvimento de produtos, transporte e comunicação acabam por ampliar as condições para que haja concentração nas cidades-regiões. Tal ampliação vincula-se a setores econômicos que exigem condições bastante diversas, como as indústrias de alta tecnologia, serviços comerciais e financeiros, dentre outros, requerendo mão-de-obra altamente qualificada, redes cada vez mais ágeis, já que submetidas a oscilações constantes em termos mercadológicos, de exigências de clientes, fornecedores, etc. Nesta perspectiva, as empresas cada vez mais especializadas e flexíveis se caracterizam por incertezas, instabilidade e complexidade e se concentram como forma de reduzir custos.

E aí as vantagens competitivas da co-presença - as economias de aglomeração - das empresas se constituem porque realizam diversas transferências e articulações entre si em forma de redes. Tal concentração incentiva a inovação e a criatividade em diferentes setores, incluso os nichos mais dinâmicos da economia contemporânea como as indústrias de alta tecnologia, serviços e indústrias de produtos culturais (SCOTT et. al., 2001). Assim, diferentes empresas e atores que conformam as redes acima referidas obtêm eficiência a partir de agrupamentos espacialmente concentrados e estritamente interligados. Destas, destacam-se a produtividade e o desempenho empresarial, com redução de custos e intensificação da criatividade, aprendizagem e inovações, com fortes vínculos transacionais em redes industriais, articuladas à economia globalizada. Assim, as cidades-regiões continuam a ser, do ponto de vista da funcionalidade, o lócus principal das atividades contemporâneas da gestão, poder e a expressão passa a designar uma estrutura territorial que, do ponto de vista morfológico, congrega duas ou mais regiões metropolitanas e aglomerações urbanas, como resultado de sua expansão física num processo complexo e simultâneo de descentralização e recentralização (SCOTT, et. al., 2001, p. 17)

Importante ainda a referência ao trabalho de Hall (2011), que ao retomar a discussão sobre as cidades mundiais, argumenta que com a globalização combinada com a informacionalização, ocorreu maior separação entre produção e serviços avançados dos negócios. Mediante uma produção cada vez mais dispersa em termos mundiais, enquanto os serviços estão cada vez mais concentrados em poucas cidades, criou-se uma hierarquia entre as cidades mundiais, que também concentram sedes de empresas, bancos, seguros e poder, estabelecendo uma competição entre elas. Isto se deve, em parte, à expansão da informacionalização da economia. O autor entende que o conteúdo de informação e inovação tornou-se mais proeminentes no último século e meio, e analisa esta evolução com base nos ciclos longos de Kondratieff e nas análises de Schumpeter. A partir de então efetua as correlações com a criação e evolução das cidades mundiais em seu caráter funcional.

Assim, no ciclo longo ocorrido na primeira metade do século XIX, os avanços na comunicação foram discretos e indiretamente ligados ao sistema de transporte que acelerou o intercâmbio das cartas. Na segunda metade do século XIX, grandes avanços no transporte ferroviário e marítimo, acrescidas as inovações no telégrafo, permitiram a separação entre mensagem e portador humano. No terceiro ciclo longo, primeira metade do século XX, ocorreu uma explosão de inovações tecnológicas de informação, mas estas ainda não eram elétricas apresentando caráter mecânico. “[...] o casamento da eletricidade e informação ocorreu logo após a II Guerra Mundial, embora as inovações tenham sido criadas antes e durante a guerra" (HALL, 2011, n. p.). Foi neste ciclo, iniciado após a guerra que ocorreram avanços fundamentais na informação que pela primeira vez "[...] dirigia a economia, tanto por meio de inovações em tecnologia de produção (o computador, a máquina copiadora) e também através do desenvolvimento de tecnologias de consumo (transistor de rádio, televisão, gravação de áudio e vídeo)" (HALL, 2011, n. p.).

Em sua interpretação, a expansão das redes de telecomunicações e informações, não interrompeu a comunicação face-a-face, ao contrário, a expansão de modernos sistemas de transporte 
(trem bala, avião) vinculados à expansão dos negócios e serviços diversos, criou demandas para a ampliação dos turismos de negócios nas cidades globais, que é sinérgico com outros setores de crescimento econômico.

Para Hall $(2011$, n. p.) as cidades globais “[ ...] são áreas muito grandes da atividade econômica - produção, movimentação de cargas, serviços de rotina - para outras cidades, regiões e países". Estas cidades estão passando ainda por rápido crescimento em serviços financeiros e empresariais; e os não financeiros também, incluindo serviços de design de rápida expansão como engenharia, arquitetura e moda; funções de comando e controle mediante sede de empresas nacionais e internacionais, sede de organismos internacionais de governo, de indústrias criativas, culturais, turismo e lazer de negócios.

Neste quadro geral, emerge para o autor uma hierarquia de cidades, tendo a global ou internacional no topo, vinculando-se à produção de serviços especializados de informação, financeiros, mídia, educação, saúde, etc. Abaixo viriam, no contexto europeu, as sub-globais, seguidas das metrópoles regionais que ocupam papel importante no sistema urbano mediante serviços administrativos e de nível superior, ocupando nichos de mercados específicos.

Diante do conjunto apresentado, importa algumas considerações: inicialmente é possível entender que a construção teórica sobre metrópole e os termos de sua construção variam no espaço e no tempo. Epistemologicamente, a natureza da metrópole passou por diferentes abordagens: aquelas que têm na concepção de comunidade sua base analítica; as pautadas nos princípios das teorias econômicas neoclássicas e as que analisam a metrópole com base em conceitos marxistas, mas a ressaltarem a globalização como uma interpretação plausível para a reestruturação econômica imposta pelo neoliberalismo.

No entanto, mesmo sob abordagens distintas, aparecem aspectos semelhantes. Em todas as referências aqui tratadas, a natureza conceitual da metrópole vincula-se ao poder econômico oriundo de diferentes atividades, passando historicamente pelo comércio regional, pela indústria, pelo sistema financeiro. Neste sentido, observa-se que as mudanças nos elementos que são colocados como fundamentais ao poder metropolitano, seguem percursos do desenvolvimento do próprio sistema capitalista. Se no final do século XIX e princípio do XX, o destaque era o comércio regional e o sistema bancário/financeiro, isso remete a dois aspectos importantes: tanto nos EUA como na Inglaterra, estava em curso o avanço do capitalismo financeiro, do qual a produção é elemento crucial. E as estruturas destes sistemas localizavam-se na metrópole, bem como aquela do comércio regional a partir do qual realizava - se amplo processo de distribuição de mercadorias. O segundo aspecto vincula-se ao fato de que, historicamente, a produção industrial estava relativamente dispersa nas cidades da região metropolitana, enqunto a cidade principal concentrava as atividades de recebimento e distribuição da produção e era o nó principal do então sistema de transporte e comunicação. Em outros termos, no período referido acima, a metrópole funcionalmente considerada, era o lócus do poder via comércio regional, produção industrial, sistema bancário e comunicação, além dos elementos políticos e culturais.

A partir dos anos de 1950, em linhas gerais, ocorreram alterações nos elementos do poder metropolitano, agora centrado cada vez mais nos mecanismos de controle da produção industrial, já que a mesma passou desde os anos de 1920, pela desconcentração física a partir dos avanços nos sistemas de comunicação, informação e expansão do uso de inovações tecnológicas; separação geográfica entre produção propriamente dita e controle/gestão implicou por um lado, na ampliação dos serviços relacionados ao controle e gestão - os serviços quaternários de Gottmann (1990) incluindo a expansão das pesquisas em direção a invenções e inovações tecnológicas na metrópole. Por outro lado, criou-se caminhos para a expansão de grandes corporações multifuncionais e multilocalizadas, que já vinham sendo criadas desde o começo do século XX, dominando a economia com sedes nas metrópoles por causa das economias externas, facilidades de contatos interorganizacionais, disponibilidade de serviços comerciais, consultorias diversas, informação e acessibilidade. 
Assim, se mais recentemente é colocado como elemento do poder metropolitano o fato das mesmas terem se tornado os nós de redes da economia mundial, a partir de novas tecnologias de informação e comunicação, pouco se acrescenta às análises precedentes. Em primeiro lugar, as redes de cidades no capitalismo se desenvolveram mediante estabelecimento de princípios de competição e complementaridade, da qual emergia uma diferenciação entre as mesmas em termos de importância derivada de suas atividades econômicas - quantidade e domínio de mercado consumidor na escala mundial. Da mesma forma, elas estavam interligadas, só que por diferentes sistemas de comunicação, com intensidade e tempo necessário para a realização das mesmas, eram maiores que os atuais. Em segundo lugar, o domínio do sistema de comunicação e informação pela metrópole ocorre há muito tempo; o que mudou foi o sistema técnico de comunicação, fruto de avanços tecnológicos que permitiram reduzir em muito a velocidade da informação, comunicação, transmissão de dados, ideias, ordens, etc. Mas, estas continuam sendo dominadas pelas grandes corporações, sediadas em metrópoles, em favor de suas unidades interligadas mundialmente.

Da mesma maneira, colocar que as cidades globais, mundiais, megacidades, metápolis, etc., tornaram-se as principais ao gerenciamento e controle das grandes corporações e lugar da produção de inovações para a indústria, é retomar ideias e elementos anteriormente colocados, conforme pode ser verificado no início do presente texto. Igualmente a compreensão da metrópole como uma grande bacia de emprego, habitação e atividades integradas no funcionamento da mesma, reforça a compreensão da funcionalidade metropolitana discutida particularmente com Berry e Horton (1970).

Nas análises mais recentes, tem sido dada particular importância à ampliação dos serviços denominados superiores, como se fossem novos ao poder metropolitano, deixando de considerar as análises precedentes como as de Gottmann (1990). Ora, desde a Segunda Guerra Mundial ocorreu um intenso processo de ampliação destes serviços ligados tanto ao gerenciamento da produção, ampliação do sistema financeiro, consumo, etc. - com acentuação da divisão social do trabalho - bem como, ampliação dos serviços administrativos no âmbito do Estado, seja para o atendimento das demandas do capital como aqueles dos serviços públicos de consumo coletivo e infraestrutura para a grande maioria da população. Desta forma, entende-se que a natureza conceitual da metrópole vinculada à sua funcionalidade, continua sendo o poder que em cada etapa histórica modifica-se em razão das necessidades decorrentes da produção e reprodução do capital.

\section{O ESPAÇO INTRAURBANO DA METRÓPOLE}

Esta dimensão analítica da metrópole também é bastante ampla e complexa, contando com rica bibliografia em diferentes ciências, temporalidades e abordagens. De modo geral, as análises passam por três grandes subdivisões: as que analisam a divisão social do espaço, que se traduzem nas diferentes áreas residenciais; as que discutem a divisão econômica do espaço, referida às atividades econômicas e suas diferentes localizações (MARCUSE, 2000); e as que analisam a formação do espaço metropolitano, que nos limites do presente trabalho não serão discutidas. Três subdivisões que não abarcam todas as possibilidades de estudos, mas são as predominantes na geografia. $\mathrm{Na}$ divisão econômica do espaço, emergem temáticas sobre centralização e descentralização, subcentros comerciais tradicionais, shopping-centers, desdobramento dos centros principais, etc. Isto porque as atividades comerciais desempenham papel crucial na estruturação da metrópole, seja pela formação de distrito central de negócios na cidade capitalista a partir do século XIX, seja pelo processo de descentralização, que em linhas gerais, principia-se na década de 1920 e permanece até os dias atuais. Quanto aos estudos sobre a divisão social do espaço via residências, esta envolve a segregação residencial em suas complexas realizações.

\section{A DIVISÃO ECONÔMICA DO ESPAÇO}

Um dos primeiros trabalhos a discutir esta temática foi o de Haig (1968), publicado originalmente em 1926. O foco central do artigo foi explicar que a descentralização das atividades econômicas 
na metrópole é seletiva, isto é, a distribuição de atividades para cada área tende a ser determinada pelo princípio da minimização dos custos, correlacionada ao preço dos terrenos e do transporte como elementos fundamentais. Para o autor, a pressão por espaço envolvendo elevados custos, provocou deslocamentos de várias atividades para a periferia e/ou cidades da região metropolitana. Ao mesmo tempo, destacava que a escala de negócios é fator crucial para a descentralização e para as articulações das "partes" das atividades, com maior facilidade de deslocamento para as menores empresas.

Haig (1968) discutia que na década de 1920 estava ocorrendo a descentralização em Nova York, primeiramente das indústrias por serem grandes consumidoras de espaço; depois as atividades de consumo frequente, seguida por diversos serviços. Mas, ressaltava que a sede das indústrias, escritórios e firmas diversas permaneceram na área central da metrópole. Ocorreu ainda a subdivisão territorial das funções que antes eram unidas no mesmo lugar, pois algumas atividades produtivas - particularmente as industriais - podem ser separadas em locais da produção propriamente dita e a gestão, esta última permanecendo na área central. Contudo, ao mesmo tempo em que ocorria a subdivisão territorial das atividades, certas vantagens podiam provocar a coesão de funções em dado lugar. Coesão, segundo Corrêa (1995) é um processo espacial entendido como um movimento que gera concentração de uma mesma atividade em um lugar, verificando-se economias externas de aglomeração. A forma espacial assumida pelo processo são as áreas especializadas em determinadas atividades comerciais ou prestadoras de serviços. Mas Haig (1968) não colocava em discussão o papel da área central, ao contrário, demonstrava que a mesma continuava a ser o lugar de concentração do poder, estando no topo da hierarquia econômica da metrópole.

Colby (1958) também analisou o processo de descentralização das atividades econômicas a partir das forças centrífugas e centrípetas. As primeiras relacionam-se a fatores de expulsão das atividades comerciais e prestadoras de serviços da área central, podendo-se destacar o constante aumento do preço dos terrenos, dos aluguéis e impostos; aumento do tráfego com os congestionamentos e elevados custos dos transportes; dificuldades de obtenção de terrenos livres para expansão das atividades; restrições legais e ausência de amenidades. As forças centrípetas correspondem a diversos atrativos para as atividades econômicas se localizarem na área central, como as atrações do lugar; conveniência funcional; magnetismo funcional; prestígio funcional e a "equação humana", vinculada a fatores pessoais ou desejos de residir ou instalar atividades na área central. Ressalte-se que o autor também identificava no processo de descentralização das atividades econômicas na metrópole, as qualidades atrativas da zona periférica, com destaque para a disponibilidade de terras não ocupadas; baixo custo e impostos; a infraestrutura; facilidade de transportes; qualidades do sítio; ausência de restrições legais e a presença de amenidades. Ao mesmo tempo, Colby (1958) discutia diferentes caminhos para a descentralização das atividades no espaço urbano metropolitano e ainda destacava a área central como a mais importante pelo fato de ser ponto focal do sistema de transporte intrametropolitano, regional e inter-regional e ainda o local de concentração das principais atividades comerciais e prestadoras de serviços na década de 1930 nos EUA. Mas, Haig (1968) já havia apontado que as lojas de departamento estavam em processo de descentralização.

Outra referência que destaca todo um conjunto de processos em direção a descentralização, criando cada vez maior complexidade no espaço urbano metropolitano, é o de Proudfoot (1958), que classificou e caracterizou a estrutura comercial norte americana em cinco tipos ideais em 1937: o distrito central de negócios; o centro periférico de negócios; eixos principais de negócios; ruas de comércio de bairros e grupo de lojas isoladas. A partir deste, outros estudos foram realizados, inclusive outras elaborações teóricas como os de Kelley (1970), Hoyt (1958), Vance Jr. (1970), destacando-se ainda Raticliff (1958) que analisou a dinâmica da descentralização a partir dos custos das terras e o efeito da distância. Todas essas referências são importantes para o entendimento do enorme crescimento das metrópoles norte-americanas do início do século XX até meados do mesmo. Nessa trajetória, os autores identificam o processo de descentralização das atividades terciárias, efetuam propostas teóricas para seu entendimento, mas deixam claro que o núcleo central de negócios ainda tem a supremacia das atividades comerciais e prestadoras de serviços. 
Essa é a posição de Berry e Horton (1970 b), que ao discutir a estrutura comercial varejista, estabelece um esquema hierárquico da distribuição destas atividades. Este demonstra parcialmente os efeitos do processo de descentralização, envolvendo a área central, eixos e áreas especializadas. Mas, entendem que estas atividades ainda estão fortemente vinculadas à área central, pois a mesma ainda concentra as atividades de gestão no âmbito metropolitano, bem como aquelas regionais. Mesmo com o crescimento de outros centros comerciais periféricos mediante expansão do automóvel, o esquema representa ainda, uma natureza hierárquica similar a das localidades centrais (BERRY, HORTON, 1970 b, p. 456).

Os autores até aqui referidos, fruto de uma seleção, apresentam em comum o fato de indicarem que o processo de descentralização foi iniciado a partir da década de 1920, principiando com as indústrias, seguida pelas atividades terciárias; embora não explícito, mas denota-se que foi a partir da década de 1940, mediante forte expansão do automóvel que ocorreu a formação, expansão de áreas especializadas e eixos com atividades comerciais. Em comum ainda, mesmo verificando-se forças centrífugas em relação à área central, é o fato de que a mesma não perdeu sua posição de maior importância na metrópole, pelo menos até a década de 1960/1970.

Essa é uma afirmação de Hoyt (1964) de que nas décadas referidas, ocorreu importante redução da população das áreas centrais das principais metrópoles; que as cidades das regiões metropolitanas cresciam mais que a cidade principal; aumento da renda per capita da classe média; profusão do automóvel e ampliação das rodovias e anéis viários, etc. como fatores dinâmicos para o processo de descentralização. Os serviços, particularmente os de gestão, ainda tinham forte presença nas áreas centrais das metrópoles, mas já identificavam a tendência dos mesmos se instalarem em áreas residenciais de alto padrão (HOYT, 1964).

Teoricamente, as análises apresentadas apoiaram-se fundamentalmente no preço da terra e custos dos transportes para entender o processo de descentralização. Trata-se, portanto, da teoria do valor da terra e valor de uso, pois quanto maior a distância do centro, menor o preço da terra e vice-versa. Contudo, as análises sobre a centralização e descentralização vão passar por importantes alterações a partir dos anos de 1970, tanto do ponto de vista da abordagem teórica como da própria forma espacial que tais processos vão assumir na metrópole.

Um primeiro aspecto nessa fase do entendimento e análise da estrutura interna da metrópole a partir das atividades terciárias é o fato de que os processos de centralização e descentralização correspondem a um caso particular da concentração e desconcentração. Estes últimos são processos gerais, enquanto os primeiros advêm da construção conceitual utilizadas para a área central de uma cidade - que inclui o núcleo central de negócios e a área periférica do mesmo (CORRÊA, 1996) referindo-se, portanto, a um processo espacial.

Neste sentido, para Corrêa (1995), processo espacial pode ser entendido como um conjunto de forças atuando ao longo do tempo e postas em ação por diversos agentes sociais de produção do espaço urbano, gerando localizações e relocalizações. Para o autor, a centralização corresponde a um caso particular da concentração, enquanto a descentralização corresponde a uma particularidade da desconcentração. No caso das metrópoles e grandes cidades, a centralidade inclui o núcleo central de negócios e outros pontos focais de atividades comerciais e de serviços, como os centros regionais, centros de bairros, shopping-centers. E aí o processo de descentralização cria também outras centralidades.

Segundo Reis (2009), a partir dos anos de 1970 ocorreu profundas transformações na distribuição das atividades econômicas até então típicas das áreas centrais. Criaram-se outras centralidades que "[...] derivadas da intensificação do processo de descentralização, irão caracterizar a emergência do fenômeno urbano que se convencionou designar nas décadas de 1980 e 1990, sob a noção multívoca de cidade policêntrica" (REIS, 2009, p. 178). As análises de Lefebvre (1991, 1999) passaram a ser fundamentais para o entendimento destas novas centralidades que são estruturadas no espaço urbano metropolitano. 
De modo geral e, com referência à metrópole norteamericana, a descentralização passou a exprimir novas expressões de centralidade intraurbana, em que sua importância passou a ser equivalente ou mesmo superior a do núcleo central, que sucessivamente passou a perder parte das atividades e atributos que tradicionalmente o definiam. E neste percurso tem-se a continuidade de uma descentralização na forma espacial de subcentros comerciais, entendidos como réplicas em menor escala do núcleo central, apresentando um conjunto de atividades presentes na primeira. Muitas das lojas e serviços podem ser filiais daquelas presentes na área central, sendo também foco de transportes intraurbano que se conecta tanto à área central como a outros subcentros de mesmo nível e aos bairros que atende, sendo elemento de articulação no espaço urbano. Estes subcentros podem ser hierárquicos ou especializados, em áreas ou eixos espontâneos ou planejados. Emergem ainda distritos de gestão, associados à presença de atividades administrativas de diferentes escalas de atuação, desde prefeituras, fóruns, câmaras municipais, passando por sedes regionais de órgãos governamentais estaduais e federais. Inclui-se nestes distritos, a presença de sedes ou filiais de empresas ou grandes corporações que articulam - se a diferentes escalas de poder.

Tem-se ainda o núcleo central desdobrado ou secundário, entendido como "[...] um setor de expansão da cidade, no qual emerge um conjunto complexo de formas de coesão, dentre as quais, além do eixo principal de comércio e serviços típicos do núcleo central de negócios, destacam-se os centros comerciais planejados, shopping-centers, hipermercados, ruas e áreas especializadas em escritórios, bancos, comércio e serviços varejistas especializados" (REIS, 2009, p. 190). Este insere-se nas áreas de maior poder aquisitivo, acrescentando-se que tanto o distrito de gestão como o núcleo central desdobrado podem ser oriundos de interesses externos ao núcleo central de negócios. No entanto, alguns aspectos precisam ser considerados para a análise destes processos.

A base para a centralização continua a ser a seletividade espacial, em que cada atividade comercial e prestadora de serviços busca padrão específico de localização, variando conforme o poder econômico de cada sociedade, a dimensão do mercado, dentre outros. Por isso, os mecanismos de demanda continuam importantes para compreender a seletividade espacial. As economias de aglomeração geradoras de coesão, também auxiliam o entendimento da centralização. No que tange à descentralização, um dos fatores importantes continua a ser as deseconomias de aglomeração, mas que se articulam, ainda, à ação de incorporadores, promotores imobiliários, proprietários fundiários e uma elite especulativa que detém poder econômico e apoio do poder público, que influi ou mesmo defini áreas onde outras centralidades serão criadas. Nesta perspectiva, Crouzet (2003) apresenta uma discussão sobre a desconcentração das sedes das empresas para subúrbios das metrópoles, articulado às discussões sobre os negócios imobiliários como atividade que se traduz como a mais visível do capital flutuante e fluido da financeirização da economia. $\mathrm{O}$ autor explica que a financeirização da economia e o jogo dos diferentes agentes instaura a desregulação da organização do território metropolitano, influindo em toda produção espacial da cidade. Assim, os negócios imobiliários aumentam as características metropolitanas de certos espaços, mas acelera sua dinâmica através de sua capacidade de fazer e desfazer as mesmas estruturas na cidade.

Nesta nova etapa de abordagem do processo de descentralização a partir dos anos de 1980, as análises de Lefebvre $(1991,1999)$ muito contribuíram para o entendimento do mesmo. A começar pelo fato de que abordar descentralização implica obrigatoriamente na análise da centralidade no espaço urbano, em cujo movimento criam-se novas dinâmicas urbanas, particularmente nas metrópoles. Por isso, o autor afirma que não existe realidade urbana sem um centro, seja ele comercial, simbólico, de informação ou de decisão, e a centralidade revela a essência da dimensão urbana (LEFEBVRE, 1991). Referindo-se ao processo de implosão-explosão da cidade, o autor explica que o fenômeno urbano se estende sobre grande parte do território, mas

[...] não sem diferenciações locais e sem ampliação da divisão (técnica e social) do trabalho para as regiões, aglomerações e cidades. Ao mesmo tempo, nesse tecido e mesmo noutros lugares, as 
concentrações urbanas tornam-se gigantescas; as populações se amontoam atingindo densidades inquietantes (por unidade de superfície ou habitação). Ao mesmo tempo ainda, muitos núcleos urbanos antigos se deterioram ou explodem. As pessoas se deslocam para periferias distantes, residenciais ou produtivas. Escritórios substituem os apartamentos nos centros urbanos. Às vezes (nos Estados Unidos) esses centros são abandonados para os 'pobres' e tornam-se guetos para os desfavorecidos. Às vezes pelo contrário, as pessoas mais abastadas conservam fortes posições no coração da cidade (LEFEBVRE, 1991, p. 10).

Dessa forma, é possível entender que a centralidade se realiza dialeticamente, pois a saturação impulsiona a criação de outras centralidades, a "[...] a policentralidade, à oniscentralidade, à ruptura do centro, à disseminação, tendência que se orienta seja para a constituição de centros diferentes (ainda que análogos eventualmente complementares), seja para a dispersão e para a segregação" (LEFEBVRE, 1999, p.112-113). Acrescenta o autor que no espaço urbano,

[...] o estudo de sua lógica e de suas propriedades formais conduz à análise dialética de suas contradições.

O centro urbano é preenchido até a sua saturação; ele apodrece ou explode. Às vezes, invertendo seu sentido, ele organiza em torno de si o vazio, a raridade. Com mais freqüência, ele supõe e propõe a concentração de tudo o que existe no mundo [...] Qualquer ponto pode tornar-se o foco, a convergência, o lugar privilegiado. De sorte que todo o espaço urbano carrega em si esse possível-impossível, sua própria negação. De sorte que todo espaço urbano foi, é, e será concentrado e poli (multi) cêntrico (LEFEBVRE, 1999, p. 46).

Portanto, o entendimento da divisão econômica do espaço, implica o entendimento dos processos de centralização e descentralização, envolvendo uma gama multivariada de formas assumidas pelos mesmos e articuladas a uma sociedade historicamente determinada.

\section{A DIVISÃO SOCIAL DO ESPAÇO}

Um dos primeiros textos a discutir de modo geral, a temática, foi o de Engels (1985). O foco central da análise era o das condições da classe operária nas grandes cidades inglesas na segunda metade do século XIX. Mas, o autor explicita a segregação residencial quando aborda as mudanças na localização das áreas residenciais da burguesia e dos trabalhadores. Estes últimos ocupavam a área central, enquanto a burguesia foi para a periferia que apresentava amenidades. A citação a seguir dá uma aproximação dos diferentes mecanismos utilizados pela burguesia para estabelecer suas áreas residenciais. "[...] a parte leste e nordeste de Manchester é a única em que a burguesia não se instalou, pela forte razão de que o vento dominante, que sopra durante dez ou onze meses do ano, de oeste a sudoeste, arrasta para aí fumaça de todas as fábricas. Esta fumaça os operários que a respirem sozinhos" (ENGELS, 1985, p. 72).

Daquelas condições discutidas pelo autor até os dias atuais, longo percurso analítico foi trilhado, no qual destaca-se que tanto na literatura produzida no âmbito da Escola de Chicago, como na geografia teorética e marxista, há consenso de que a segregação se refere a questão residencial e é a expressão mais acabada da segregação do espaço.

Conceitualmente, a segregação tem em Castells (1983) importante contribuição ao correlacionar a distribuição das residências com as leis gerais de distribuição dos produtos na sociedade capitalista, variando conforme o nível de renda, status profissional, etnia, dentre outros. Neste percurso, trabalhando com estratificação urbana, o autor transpõe a idéia de estratificação social, sendo a segregação "[...] a tendência à organização do espaço em zonas de forte homogeneidade social entre elas, sendo esta disparidade compreendida não só em termos de diferença, mas também de hierarquia" (CASTELLS, 1983, p. 210). Convém ressaltar, que o movimento tendencial de formação de zonas residenciais distintas, bem como de relativa homogeneização (nunca absoluta) está ligado a semelhanças. Neste sentido, é importante discutir a homogeneidade e heterogeneidade 
vinculada a uma dada escala analítica, pois emerge então a relatividade da análise, já que ambas são construções intelectuais a partir de dada escala.

Dessa forma, é preciso considerar que as áreas homogêneas em sua relatividade se caracterizam por diferentes indicadores (renda, ocupações, migrações, etc.) e variáveis (renda média familiar, renda do chefe familiar, etc.), cujas combinações permitem compreender o conteúdo da segregação. Neste aspecto, estudos da Escola de Chicago e daqueles no contexto da geografia teorética, permitiram ampla descrição da segregação.

Mas, além da descrição, a segregação precisa ser entendida a partir do nascimento das cidades (MUNFORD, 1998), pois com a emergência de uma elite, esta separa-se do campo e constitui outra área de residência. É na origem da cidade que está a segregação residencial (SINGER, 1985).

Segregação residencial é fruto da sociedade de classes e com Harvey (1975) tem-se importante contribuição analítica. Rejeitando a explicação da economia neoclássica de que a diferenciação residencial vincula-se à soberania do consumidor e a análise da homogeneidade e heterogeneidade de Castells (1983), argumenta que na sociedade capitalista de meados do século XX, a estruturação das classes sociais e suas frações, advêm de relações entre as forças primárias, residuais e derivativas. As primeiras representam as classes dos donos de meios de produção e da força de trabalho; as residuais configuram-se em classes sociais de outros modos de produção, a exemplo de latifundiários e grupos de imigrantes de origem rural, não integradas plenamente à economia capitalista; as derivativas são oriundas do próprio avanço do capitalismo, cuja maior complexidade em termos de produção, circulação e consumo, possibilita o aparecimento de novas atividades, profissionais e status.

Deste modo, argumenta o autor, torna-se cada vez mais complexa a sociedade capitalista, fragmentada em classes e inúmeras frações de classes. Segundo Harvey (1975), estas forças geraram: fragmentação das classes capitalistas pela divisão do trabalho, emergindo vários estratos; consequentemente criam-se distintas classes de consumo; aparecimento de uma classe média burocrática, que atua no âmbito do estado e grandes empresas, apresentando grandes diferenças em termos de renda, origem, etc.; desvio de consciência de classe e recriação de mecanismos de controle à mobilidade social.

Como estas forças são contraditórias, algumas levam a um antagonismo de configurações sociais, enquanto outras criam diferenciações favoráveis à reprodução da complexa fragmentação social. Assim, a segregação residencial traduz-se na localização diferenciada no espaço urbano das distintas classes e frações. Neste sentido, pode-se discutir alguns aspectos da lógica espacial da segregação, a começar pela apropriação e valorização diferenciada da terra urbana, gerando áreas residenciais profundamente distintas conforme as classes e suas frações.

Mas, é importante referir que os estudos sobre a segregação residencial são de longa data e um dos primeiros a estudar padrão da segregação foi J. G. Kohl em 1841, identificando na Europa a existência de um padrão centro - periferia: os ricos residiam no centro enquanto os pobres estavam na periferia. Segundo Kohl, esse era o padrão da cidade pré-industrial, situação esta bastante distinta daquela identificada por Engels (1985) para a Inglaterra da segunda metade do século XIX: população trabalhadora no centro e a burguesia na periferia. Esta situação demonstrada por Engels (1985) foi tornada o modelo dos círculos concêntricos de E. W Burgess, publicado em 1925. No entanto, Hoyt (2005) apresenta outra forma de realização da segregação, através do modelo dos setores, como tendências gerais para a localização de áreas residenciais de diferentes status econômicos e sociais. Em realidade, os três modelos - Kohl, Burgess e Hoyt - podem ser entendidos como referenciais para a compreensão da dinâmica da segregação.

Outras referências importantes sobre o tema são as de Yuynovsky (1971) e Bähr e Mertins (1983) para as metrópoles latinoamericanas. Segundo os autores, a cidade latinoamericana apresenta as três lógicas de segregação de modo muito complexo, já que há permanências e mudanças. Assim, para Yuynovsky (1971), na América Latina até 1850 predominava nas cidades a residência 
das elites junto ao centro enquanto a população trabalhadora residia na periferia; de 1850 até 1930 , ocorrem mudanças na localização das áreas residenciais, invertendo a situação até então encontrada. As profundas mudanças econômicas, sociais, políticas - independências nacionais, início da industrialização para vários países, implantação de sistema de transporte ferroviário, fim da escravidão, etc. - fizeram com que a elite saísse do centro. Após 1930, segundo o autor, ocorreu ratificação e complexificação do processo de segregação cujas formas espaciais assumidas são as mais diversas.

Bähr e Mertins (1983) analisando especificamente um modelo de diferenciação socioespacial, dão destaque a uma representação típica dos bairros localizados na zona periférica do centro e na periferia das metrópoles, articuladas ao processo de migração. Para os autores, a área central passou a ser ocupada pelos grupos de baixo poder aquisitivo, cujas antigas residências das elites foram subdivididas e alugadas para trabalhadores migrantes. Mas, mediante ocupações ilegais, a população trabalhadora também passou a se localizar na periferia das metrópoles; ocupações semi legalizadas, com terreno adquirido nos termos da legislação, mas cujo processo de edificação das unidades não se dá com a permissão das autoridades; ocupações legalizadas via programas de governos, como são os conjuntos habitacionais brasileiros.

Embora já esteja bastante discutido que periferia seja um conceito socialmente construído, cujo significado oscila no tempo e espaço, frisa-se que este precisa ser, claramente, identificado na análise sobre segregação socioespacial, porque conforme assinalou Corrêa (1986), envolve simultaneamente a produção do espaço urbano, a acumulação de capital e reprodução da força de trabalho. Enquanto objeto de ação das classes dominantes, a periferia insere-se

[...] de um lado, no processo de acumulação de capital, seja através da incorporação e produção imobiliária, seja através da extração de urna renda fundiária, seja através da utilização de terrenos baratos para implantação industrial e de serviços diversos. De outro insere-se no processo de controle social através da reprodução segregada das diferentes classes sociais e suas frações. Ambos os aspectos, acumulação e reprodução, são interdependentes (CORRÊA, 1986, p. 73).

Desta forma, é preciso considerar que há periferias e periferias. Aquelas que são apropriadas pelas classes dominantes, apresentam infraestruturas, serviços diversos e atividades comerciais de alto status, enquanto aquela popular manifesta a ausência de condições mínimas de sobrevivência, nela se reproduzindo gigantesca parcela do exército industrial de reserva (CORRÊA, 1986).

Nas últimas décadas do século XX, tal processo atingiu maior complexidade e Marcuse (2000) metaforicamente denominou de cidade em "pedaços", como recurso à analise da continuidade da fragmentação social no capitalismo e como cada uma delas é posicionada em determinadas localizações geográficas. Além de separações por funções e usos, a cidade se aparta em classes, raças, etnias e estilos de vida (MARCUSE, 2000). A divisão por classes e raça tendencialmente è hierarquizada e socialmente determinada, enquanto as duas últimas tendem a ser cultural e voluntária. Mas o autor ressalta que na divisão da cidade, dois fatores são fundamentais: a renda e poder. Disto deriva a cidade em "pedaços".

- A cidade do luxo e do controle, onde vive uma elite que não mantém contato direto com a cidade; cujos membros exercem controle sobre a base econômica e às vezes política, na escala nacional e internacional, conformando cidadelas ou enclaves;

- A cidade gentrificada, traduzida como a presença de uma classe empresarial em crescimento, altamente qualificada e ligada aos serviços avançados, capaz de influir na estrutura urbana na medida em que tem localização variável, dependendo da história, topografia, políticas públicas, etc. da cidade;

- A cidade suburbana e da produção direta, sendo local da classe média, normalmente localizada nos subúrbios e compostas por industriais e/ou pequenos empresários, trabalhadores 
qualificados, aposentados de certas ocupações profissionais. Para o autor esse é o padrão predominante de habitação nos EUA, apresentando elevada densidade;

- A cidade do cortiço e do trabalho não qualificado, sendo áreas de residências da classe trabalhadora das indústrias e de serviços de rotina, com baixas remunerações. Nestas áreas também localizam-se bairros de imigrantes;

- A cidade abandonada e da economia informal, cujas áreas são desconsideradas pelas instituições de poder público, nas quais a população residente é excluída do leque de apoio do Estado, vivendo da economia informal. Segundo o autor, os guetos podem ser parte desta cidade, vinculado ao confinamento involuntário, com base na raça (MARCUSE, 2000).

Estabelece ainda relações entre os habitantes com a migração e imigração, demonstrando uma dimensão de identidade que permite aos migrantes e imigrantes sua localização em distintos pedaços das cidades: parte dos imigrantes de alto poder aquisitivo vão para as cidadelas ou áreas de gentrificação, enquanto os migrantes internos e de baixo poder aquisitivo vão para os cortiços e cidade abandonada. Deixa claro que a segregação residencial é processo pelo qual um grupo populacional é forçado, ou seja, involuntariamente a se agrupar em uma área espacial definida, formando e mantendo guetos (MARCUSE, 2010); de modo que o autor não permite o uso da expressão autosegregação ou segregação voluntária, já que são analiticamente oximoros e insidiosos, visto ser a segregação um processo forçoso e intrinsecamente ligado às classes sociais.

Contudo, diante dos objetivos do presente trabalho, é necessário por fim, acrescentar a relação entre descentralização e segregação. De modo geral, o que se verifica a partir das análises precedentes, é que o processo de descentralização das atividades econômicas tem sido fator importante para a expansão e criação de outras formas de segregação socioespacial, particularmente a partir de meados do século XX. Primeiramente porque o processo foi fortemente ampliado mediante mudanças no sistema de transporte, em especial do automóvel; pela criação de novas estruturas comerciais varejistas através dos shopping-centers, eixos principais de negócios, ruas comerciais de bairro, sejam elas espontâneas ou planejadas; pelo próprio crescimento demográfico das metrópoles, dentre outros. Na medida em que a descentralização ocorre diferenciadamente em termos de localização e de mercado consumidor, há possibilidades de que em áreas residenciais sejam criados ou alterados seus ocupantes, em favor das diferentes valorizações criadas pela descentralização, seja ela anterior ou posterior à presença de áreas residenciais. Nesta dinâmica fortemente articulada à ação dos promotores imobiliários e do Estado, amplia-se a segregação socioespacial.

\section{CONSIDERAÇÕES FINAIS}

Por fim, em todas as referências aqui tratadas, a natureza conceitual da metrópole vincula-se ao poder econômico oriundo de diferentes atividades, passando historicamente pelo comércio regional, pela indústria, pelo sistema financeiro. Neste sentido, observa-se que as mudanças nos elementos que são colocados como fundamentais ao poder metropolitano, seguem percursos do desenvolvimento do próprio sistema capitalista. Mas, partir dos anos de $1950 \mathrm{em}$ linhas gerais, ocorreram alterações nos elementos do poder metropolitano, agora centrado cada vez mais nos mecanismos de controle da produção industrial, já que a mesma passou desde os anos de 1920, pela desconcentração física a partir dos avanços nos sistemas de comunicação e informação e expansão do uso de inovações tecnológicas. Por outro lado, criou-se caminhos para a expansão de grandes corporações multifuncionais e multilocalizadas, que vinham sendo criadas desde o começo do século XX, dominando a economia com sedes nas metrópoles, por causa das economias externas, facilidades de contatos interorganizacionais, disponibilidade de serviços comerciais, consultorias diversas, informação e acessibilidade. Assim, se mais recentemente é colocado como elemento do 
poder metropolitano o fato das mesmas terem se tornado os nós de redes da economia mundial, a partir de novas tecnologias de informação e comunicação, pouco se altera em relação às análises precedentes. O que mudou foi o sistema técnico de comunicações, fruto de avanços tecnológicos que permitiram reduzir em muito a velocidade da informação, comunicação, transmissão de dados, ideias, ordens, etc. Mas estas continuam sendo dominadas pelas grandes corporações, sediadas em metrópoles, em favor de suas unidades interligadas mundialmente. Nas análises mais recentes têm sido dada particular importância à ampliação dos serviços denominados superiores como se fossem novos ao poder metropolitano, deixando de considerar as análises precedentes como as de Gottmann (1970).

Da mesma forma, as discussões sobre as atividades terciárias e a produção do espaço metropolitano, ratificam a continuidade do processo de descentralização, reduzindo nas metrópoles, o poder do núcleo central de negócios em favor de outras centralidades mediante a policentralidade. A segregação acentua-se mediante novas lógicas de disposição e imposições de áreas residenciais, em que a população de baixo poder aquisitivo continua sendo forçada a se agrupar em áreas espaciais definidas. Importa notar, por fim, que por maior que sejam as diferenças epistemológicas das análises apresentadas, a discussão da natureza da metrópole ainda apresenta conceitos que vêm sendo consolidados de longo tempo.

\section{REFERÊNCIAS BIBLIOGRÁFICAS}

ASCHER, F. Dynamiques metropolitaines et enjeux sócio-politiques. Disponível em: $<$ http//multitudes. samizdat.net/Dynamiques-metropolitaines-et>. Acesso em 10 de fevereiro de 2011. ASCHER, F. Metápolis ou l'avenir dês villes. Paris: Odile Jacob, 1995.

BÄHR, J.; MERTINS, G. Um modelo de la diferenciación socio-espacial de las metropolis de América Latina. Revista Geográfica, IPGH, n. 98, jul./dec., 1983, p. 23-29.

BEAUJEAU-GARNIER, J. Geografia urbana. Lisboa: Fundação Calouste Gulbenkian, 1980.

BERRY, B.; HORTON, F. Internal structure: physical space. In: BERRY, B.; HORTON, F. Geographic perspective on urban systems: with integrated reading. New Jersey: Prentice Hall Inc/Englewood Cliffs, 1970, p. 440-485.

BERRY, B.; HORTON, F. Problems of defining the metropolis. In: BERRY, B.; HORTON, F. Geographic perspective on urban systems: with integrated reading. New Jersey: Prentice Hall Inc/Englewood Cliffs, 1970 b, p. 250-275.

BOGUE, Donald J. La estructura de la comunidad metropolitana. In: THEODORSON, G. A. Estudios de ecología humana. Barcelona: Editorial Labor, 1974, v. 2, p. 337-360.

CASTELLS, M. A questão urbana. Rio de Janeiro: Paz e Terra, 1983.

CASTELLS, M. A sociedade em rede. São Paulo: Paz e Terra, 1999.

CHARDONETT, Jean. Metrópolis économiques. Paris: Libraire Armand Colin, 1959. 270 p.

COLBY, C. C. Centrifugal and centripetal forces in urban geography. In: MAYER, H. M.; KOHN, C. (ed.). Readings in urban geography. Chicago: The University of Chicago Press, 1958.

CORRÊA, R. L. A periferia urbana. Geosul, Florianópolis, v. 1, n. 2, 1986. p. 70-78.

CORRÊA, R. L. O espaço urbano. São Paulo: Ática, 1995.

CORRÊA, R. L. Os centros de gestão do território: uma nota. Revista Território, Rio de Janeiro, v. 1, n. 1, 1996. p. 23-30.

CROUZET, Eric. L'immobilier de bureau dans l'espace urbain: evolutions des approaches theoriques. Geocarrefour, v. 78, n. 4, 2003. p. 269-279.

DAVIDOVICH, F. A. A “volta da metrópole” no Brasil: referências para a gestão territorial. In: RIBEIRO, L. C. de Q. (org). Metrópoles: entre a coesão e a fragmentação, a cooperação e o conflito. São Paulo: Fundação Perseu Abramo; Rio de Janeiro: FASE, 2004. 
DICKINSON, Robert. Las regiones metropolitanas en Estados Unidos. In: THEODORSON, G. A. Estudios de ecología humana. Barcelona: Editorial Labor, 1974, v. 2, p. 361-375.

ENGELS, F. As grandes cidades. In: ENGELS, F. A situação da classe trabalhadora na Inglaterra. São Paulo: Global, 1985.

FITZSIMMONS, J.; RATICLIFFE, M. Metropolitan area standards review: new definitions for census 2000. Disponível em: <www.iussp.prg/menbers/restricted/publications $>$. Acesso em 08 de outubro de 2010. FRIEDMANN, J. The world city hypothesis. Development and Change, Oxford, v.17, n.4, p.12-50, 1986. FRIEDMANN, J.; WOLFF, G. World city formation: an agenda for research and action. International Journal of Urban and Regional Research, London, n.6, p.309-44, 1982.

GOTTMANN, Jean. A dinâmica das grandes cidades. Boletim Geográfico, Rio de Janeiro, v. 34, n. 255, out./dez., 1976. p. 5-14.

GOTTMANN, J. Essais sur l'aménagement de l'espace habité. Paris: Monton \& Co, 1966.

GOTTMANN, Jean. Megalopolis or the urbanization of the northeastern seabord. In: MAYER, Harold; KOHN, Clayde (ed). Readings in urban geography. Chicago: University of Chicago Press, 1959.

GOTTMANN, Jean. Urban centrality an the interweaving of quaternary activities. In: GOTTMANN, J. ; HARPER, Robert. A. Since megalopolis: the urban writings of Jean Gottmann. Baltimore and London: The Johns Hopkins University Press, 1990.

GRAS, N. S. B. El desarollo de la economía metropolitana en Europa y en América. In: THEODORSON, G. A. Estudios de ecología humana. Barcelona: Editorial Labor, 1974, v. 2, p. 321-335.

HAIG, R. M. Toward and understanding of the metropoles. In: SMITH, R. H. T.; TAAFE, E. J.; KING, L. J. (org). Readings in economic geography. Chicago: Randy Mc Nally, 1968. p. 44-57.

HALL, Peter. Les villes mondiales. Paris: Libraire Hachette, 1966.

HALL, Peter. Megacities, word cities and global cities. Disponível em: <www.megacities.nl/lecture_1/ lecture.html>. Acesso em 10 de fevereiro de 2011.

HARVEY, D. Class structure in a capitalist society and the theory of residencial differentiation. In: PELL, R. ; CHISHOLM, M.; HAGGETT, P. Process in physical and human geography. London: Heinemann Education Book, 1975.

HOYT, H. Classification and significant characteristics of shopping Center. In: MAYER, H. M.; KOHN, C. (ed.). Readings in urban geography. Chicago: The University of Chicago Press, 1958. P. 454-461.

HOYT, H. Recent distortion of the classic models urban structure. Land Economic, v. 40, may 1964, p. 199-212.

HOYT, H. The pattern of movement of residential neighhoods. In: FYFE, N. R.; KENNY, J. (orgs.). The urban geography reader N. York: Routledge, 2005.

KELLEY, E. J. Retail structure economy. In: PUTNAM, R. et al. (Eds.). A geography of urban places. Toronto: Methuen Publications, 1970.

LEFEBVRE, H. O direito à cidade. São Paulo: Moraes, 1991.

LEFEBVRE, Henri. A revolução urbana. Belo Horizonte: UFMG, 1999.

MALECKI, Edward J. Dimensions of R\&D location in the United State. Research Policy, v. 9, n. 1, 1980, p. 2-22.

MALECKI, Edward J. Locational trends in R\&D by large US corporations: 1965-1977. Economic Geography, v. 55, n. 4, 1979. p. 309-323.

MARCUSE, P. Enclaves yes, ghettoes no: segregation and state. Disponível em: $<\mathrm{http}: / / \mathrm{www}$.urbancenter. utoronto.ca/pdfs/curp/Marcuse_Segregationandthe.pdf $>$. Acesso em 12 de novembro de 2010.

MARCUSE, Peter. Cities in quarties. In: BRIDGE, G.; WATSON, S. A company to the city. Oxford: Blackwell, 2000. p. 270-281.

MUNFORD, Lewis. A cidade na história: suas origens, transformações e perspectivas. São Paulo: Martins Fontes, 1998.

NIVEAU, M. História dos fatos econômicos contemporâneos. São Paulo: Difusão Européia do Livro, 1969. 
PARK, R. E. La urbanización medida por la circulación de prensa. In: THEODORSON, G. A. Estudios de ecología humana. Barcelona: Editorial Labor, 1974, v. 2, p. 377- 390.

PRED, A. Sistemas de cidades em economias adiantadas: crescimento passado, processos presentes e opções de desenvolvimento futuro. Rio de Janeiro: Zahar Editores, 1979.

RATICLIFF, R. The dynamics of efficiency in the locational distribution of urban activities. In: MAYER, H. M.; KOHN, C. (eds.). Readings in urban geography. Chicago: The University of Chicago Press, 1958. REIS, L. C. T. dos. Descentralização e desdobramento do núcleo central de negócios em Vitória (ES). In: CARRERAS, C. PACHECO, S. M. M. (orgs). Cidade e comércio: a rua comercial na perspectiva internacional. Rio de Janeiro: Armazém das Letras, 2009. p. 177-198.

SASSEN, S. As cidades na economia mundial. São Paulo: Studio Nobel, 1998.

SCOTT, A. J.et. al. Cidades-regiões globais. Espaço e Debates, São Paulo, n.41, 2001. p.11-25.

SEMPLE, K. L. Quaternary places in Canada. In: BRITTON, J. N. H. Canada and global economy: the geography of structural and technological change. Quebec: McGill, Queens's University Press, 1996. p. 352-379.

SEMPLE, K. R. Toward a quaternary place theory. Urban Geography, v. 6, n. 4, 1985. p. 285-296. Acesso em 12 de maio de 2011.

SINGER, Paul. Economia política da urbanização. São Paulo: Brasiliense, 1985.

SOJA, E. W. Postmetropolis: critical studies of cities and regions. Oxford: Blackwell Publishing, 2002.

VANCE Jr, James E. Emerging patterns of commercial structure in American cities. In: PUTNAM, R. et al. (eds.). A geography of urban places. Toronto: Methuen Publications, 1970. p. 201-214.

VELTZ, P. Mondialization: villes et territories: l'économie d'archipel. Paris: Presses Universitairesde France, 1996.

YUJNOVSKY, O. La estructura interna de la ciudad: el caso latinoamericano. Buenos Aires: Ediciones SIAP, 1971. 